\title{
Productivity Relations in Seawater Fish Ponds: A Comparison of Stocked and Unstocked Ponds*
}

\author{
F. Motzkin ${ }^{1}$, Y. Cohen ${ }^{2,}{ }^{3}$, H. Gordin ${ }^{1}$ and E. Padan ${ }^{3}$ \\ 1 Israel Oceanographic \& Limnological Research, Mariculture Laboratory, P.O.B. 1212, Elat, Israel \\ ${ }^{2}$ H. Steinitz Marine Biology Laboratory, P.O.B. 469, Elat, Israel \\ ${ }^{3}$ Division of Molecular and Microbial Ecology, The Hebrew University of Jerusalem, Jerusalem, Israel
}

\begin{abstract}
The interactions between nutrient load, fish activities, and developing phytoplankton were studied in a stocked seawater fish pond as compared to an unstocked seawater control pond. Both ponds received the same nutrient load from a common inflow $\left(2.7 \mathrm{~g}\right.$ at nitrogen $\mathrm{d}^{-1}$ and $0.065 \mathrm{~g}$ at phosphorus $\mathrm{d}^{-1}$ ); they were flushed at a rate of $0.6 \mathrm{~d}^{-1}$. Apparent growth rates of the phytoplankton varied from 0.62 to 1.7 in the ponds. The stocked fish pond received an extra nutrient load from the fish food ( $1.9 \mathrm{~g}$ at nitrogen $\mathrm{d}^{-1}$ and $0.14 \mathrm{~g}$ at phosphorus $\left.\mathrm{d}^{-1}\right)$; this was responsible for the higher standing crop observed in this pond, 10 to $53 \mathrm{mg} \mathrm{Chl} \mathrm{a} \mathrm{m} \mathrm{m}^{-3}$ compared to 4 to $28 \mathrm{mg} \mathrm{Chl} \mathrm{a} \mathrm{m} \mathrm{m}^{-3}$ in the unstocked control pond. The average daily primary production was $3.5 \mathrm{~g} \mathrm{C} \mathrm{m}^{-2} \mathrm{~d}^{-1}$ and $2 \mathrm{~g} \mathrm{C} \mathrm{m}^{-2} \mathrm{~d}^{-1}$ in the stocked fish pond and control pond, respectively. Remarkably, however, both ponds showed the same pattern of monthly periodicity in phytoplankton blooms. The high N:P ratios (18 to 80 ) in the inflow water and their periodical fluctuations that correlate with the blooms suggest that both systems are phosphorus limited. The tidal pattern in the gulf seems both to induce the periodicity of the inflow water N:P ratios and to govern the monthly cycle of the blooms.
\end{abstract}

\section{INTRODUCTION}

An increase in the productivity of the natural food chain characterizes fresh and brackish water fish ponds stocked either as mono- or polyculture with different species of carp. Tilapia, and grey mullets (Bardach et al., 1972; Moav et al., 1977; Halevi, 1979). Both high standing crop and primary production have been documented in such ponds (Hepher, 1962; Schroeder, 1978; Norriega-Curtis, 1979). This eutrophication is caused by the introduction of inorganic fertilizers, organic manure, and supplementary fish food (Dimitrov, 1974; Hepher, 1975).

During dense algal blooms in these ponds, high photosynthetic activity leads to supersaturated oxygen levels in the water column during the day, and fish mortalities occur due to 'gas bubble disease' (Harvey and Smith, 1961; Pauley and Nakatani, 1967). When the blooms collapse, complete oxygen depletion may occur, resulting in mass fish mortalities in the ponds (Abeliovich and Shilo, 1972; Ellof et al., 1976). Drastic $\mathrm{pH}$ fluctuations in the order of $3 \mathrm{pH}$ units within a

\footnotetext{
- Contribution, Israel Oceanographic \& Limnological Research, Haifa, Israel
}

diurnal cycle have also been encountered (Abeliovich, 1969; Amlacher, 1970). At the bottom of these ponds anaerobic sediments rich in organic matter develop, and thus the aerobic mineralization processes become inhibited. This inhibition results in dominating anaerobic fermentation, nitrate and sulphate reduction processes, and methane production (Wolfe, 1971; Brezonik, 1972; Cappenberg, 1974). Some of the end products of these microbial activities, such as ammonia and $\mathrm{H}_{2} \mathrm{~S}$, have been shown to be toxic to fish and inhibitory to fish growth (Reichenbach-Klinke, 1967; Kinne, 1976; Colt and Tchobanoglous, 1978; Seymour, 1980).

In spite of long traditions of extensive marine fish farming in the Far East, information on intensive fish farming in seawater ponds is lacking (Bardach at al., 1972; Huguenin, 1975). In developing intensive marine aquaculture, the introduction of treated sewage to marine shellfish ponds, accompanied by increased algal biomass, proved to be successful in converting nutrients into the biomass of higher marine organisms (Goldman et al., 1973; Goldman and Ryther, 1975; Ryther et al., 1975).

Recently, intensive marine fish farming in experimental seawater fish ponds was undertaken in the arid 
coastal desert area of Elat, Israel, where access to freshwater sources is limited. These seawater ponds were stocked for polyculture experiments with Sparus aurata and Mugil cephalus. Due to the carnivorous behaviour of Sparus aurata, the fish in the ponds were fed with pelleted food (Marais and Kissil, 1979); no other fertilizers were used, contrary to the practices of freshwater fish farming. Seawater fish ponds differ from freshwater ponds in a number of ways: (1) Since the seawater ponds have a continuous inflow of fresh seawater at a dilution rate of $0.58-0.62 \mathrm{~d}^{-1}$, temperature and $\mathrm{pH}$ are more stable as compared to stagnant freshwater ponds (Krant et al, in press). Salinity fluctuations in the seawater ponds are small despite high evaporation rates of $1 \mathrm{~cm} \mathrm{~d}^{-1}$ (Assaf and Kessler, 1976). (2) The seawater supplying the ponds contains excess sulphate, which enhances sulphate reduction in the sediments and thus inhibits methane production (Jørgensen and Fenchel, 1974; Abram and Nedwell, 1978). This is in contrast to the high methane production in the sediments of freshwater ponds (Cappenberg, 1974).

Despite these differences between seawater and freshwater fish ponds, a similar trend in both systems was noted of decreasing yield with increasing pond age. Annual yields in the seawater ponds decreased from $8,750 \mathrm{~kg} \mathrm{ha} \mathrm{h}^{-1} \mathrm{yr}^{-1}$ in the first year to $5,380 \mathrm{~kg}$ $\mathrm{ha}^{-1} \mathrm{yr}^{-1}$ in the fourth year (Gordin et al., 1980). Similar but more drastic trends of inhibited growth rates of fish have long been observed in intensive freshwater ponds (Avnimelech and Lacher, 1979; Rappaport and Sarig, 1979). This decrease in fish growth in the freshwater fish ponds is believed to result from the anaerobic end-product metabolites related to the eutrophication process.

The aim of the research work reported here was to study the dynamics of the algal blooms in relation to the eutrophication rates in the seawater fish ponds with an unstocked pond serving as a control.

\section{MATERIAL AND METHODS}

\section{Experimental System}

Two experimental seawater fish ponds were used at the laboratory of the Israel Oceanographic \& Limnological Research, situated in Elat on the Gulf of Elat (Aqaba). Both ponds were rectangular with gradually sloping sides and an average depth of $1 \mathrm{~m}$. The unstocked pond serving as a control pond had an area of $203 \mathrm{~m}^{2}$ and a volume of $144 \mathrm{~m}^{3}$. The other pond had an area of $223 \mathrm{~m}^{2}$ and a volume of $134 \mathrm{~m}^{3}$. The latter was stocked with 600 Sparus aurata and 50 Mugil cephalus (average density 5 fish $\mathrm{m}^{-3}$ ). Both ponds were supplied by filtered seawater which was pumped from a nearby seawater well located $20 \mathrm{~m}$ from the shoreline. The flow rate was $3.5 \mathrm{~m}^{3} \mathrm{~h}^{-1}$ to each of the ponds, and it was continuously monitored with a flow meter. The corresponding dilution rate of the control pond was $0.58 \mathrm{~d}^{-1}$ and in the fish pond $0.62 \mathrm{~d}^{-1}$. All measurements were done weekly, between $11.00 \mathrm{~h}$ and $13.00 \mathrm{~h}$, from permanent platforms at the study site in each of the ponds.

\section{Parameters Measured}

Primary production was determined by using the ${ }^{14} \mathrm{C}$ assimilation technique (Strickland and Parsons, 1968), modified in the following way: $130 \mathrm{ml}$ Pyrex bottles 'light' and 'dark' were filled with pond water and $100 \mathrm{Ci}$ of carrier free $\mathrm{NaH}^{14} \mathrm{CO}_{3}$ (Amersham, England) was added to each of them. The alkalinity was measured according to Strickland and Parsons (1968) and ranged from 2.2 to $2.6 \mathrm{mEqv}$. A 'dark' and a 'light' bottle were incubated in situ in the ponds at 3 depths: 0,50 , and $100 \mathrm{~cm}$ (bottom) for $2 \mathrm{~h}$. The water was then filtered through Whatman GF/F filter paper. The filters were acidified with fumes of concentrated $\mathrm{HCl}$ in a vacuum desiccator for $12 \mathrm{~h}$ and counted with a Nuclear Chicago $181 \mathrm{~B}$ gas flow meter. The 'dark' bottle counts were subtracted from the 'light' bottle counts.

Preliminary measurements of water movements in the ponds demonstrated the rapid mixing rates occur-

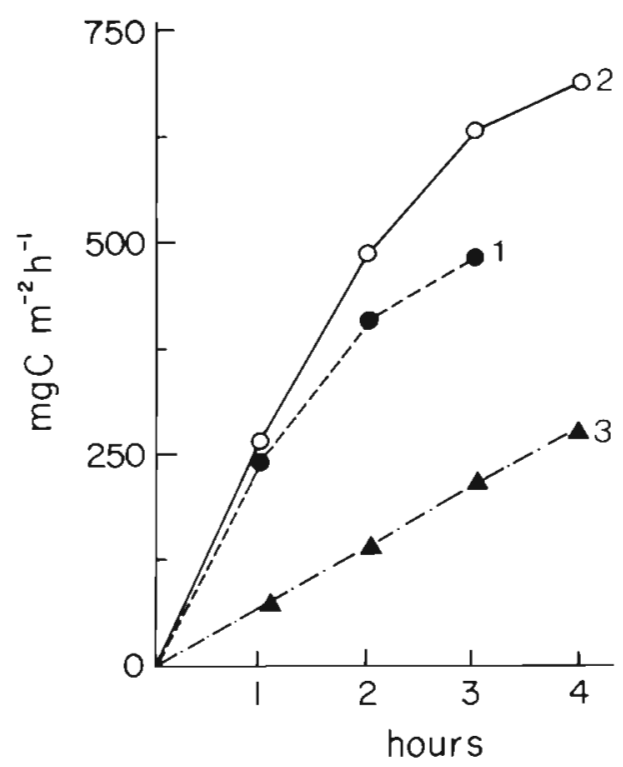

Fig. 1. Time course of primary production experiment, 25 August 1977. (1) Surface water, (2) $50 \mathrm{~cm}$, (3) bottom $(100 \mathrm{~cm})$ 
ring in them. The residence time of a particle at the surface of the water can be as short as $4 \mathrm{~min}$. This fast mixing was avoided in the closed bottles. However, a time course experiment done during a dense Skeletonema sp. bloom in the fish pond has shown that the primary production activity was linear for up to 2-h incubation. Inhibition of photosynthetic activity was only observed during longer periods of incubation (Fig. 1). Therefore, the estimation of the primary production rate was based on a 2 -h incubation period.

Light penetration was measured throughout the water column at $10 \mathrm{~cm}$ intervals with a L1-185 A quantum/radiometer/photometer equipped with a L1-192 S underwater quantum sensor that measured the photosynthetically active radiation in the $400-700 \mathrm{~m} \mu$ wavelength range. The results were expressed in Einsteins $\mathrm{s}^{-1} \mathrm{~m}^{-2}$.

Dissolved oxygen and temperature were measured with a YS1-54 oxygen analyzer equipped with an oxygen and temperature electrode. Oxygen electrode measurements were corrected using Winkler titration (Strickland and Parsons, 1968). The pH and alkalinity were determined by the Strickland and Parsons (1968) titration method. Dissolved inorganic nutrients ( $N$ $\mathrm{NH}_{4}, \mathrm{~N}-\mathrm{NO}_{2}, \mathrm{~N}-\mathrm{NO}_{3}, \mathrm{P}-\mathrm{PO}_{4}, \mathrm{Si}-\mathrm{SiO}_{2}$ ) were determined according to Grasshoff (1976).

Chlorophyll $a, b$, and $c$ concentrations were determined in $1 \mathrm{l}$ of pond water according to Strickland and Parsons (1968) using the following conversions:

(a) Chlorophyll a: $11.6 \mathrm{E}_{6650}-1.31 \mathrm{E}_{6450}-0.14 \mathrm{E}_{6300}$;

(b) chlorophyll $b$ : $20.7 \mathrm{E}_{6450}-4.34 \mathrm{E}_{6650}-4.42 \mathrm{E}_{6300} \mathrm{i}$

(c) chlorophyll c: $55.0 \mathrm{E}_{6300}-4.64 \mathrm{E}_{6650}-16.3 \mathrm{E}_{6450}$.

Phytoplankton was collected from the water column and preserved in $2 \%$ Lugol solution. Cell counts and identification were done microscopically using a Neubauer Haemacytometer (Clay-Adams).

\section{RESULTS}

We studied the interactions between nutrient load, fish activities, and developing phytoplankton by following simultaneously physical, chemical, and biological parameters in a stocked pond and an unstocked control pond.

\section{Physical and Chemical Parameters}

Previous studies have shown that both experimental ponds are completely mixed (Krant, 1979). Salinity in both ponds was stable, varying from $41.45 \%$ to $41.81 \%$ during winter, and from $41.81 \%$ to $42.18 \%$ during summer. Throughout the period studied (November 1977 to January 1979), the temperature of both ponds

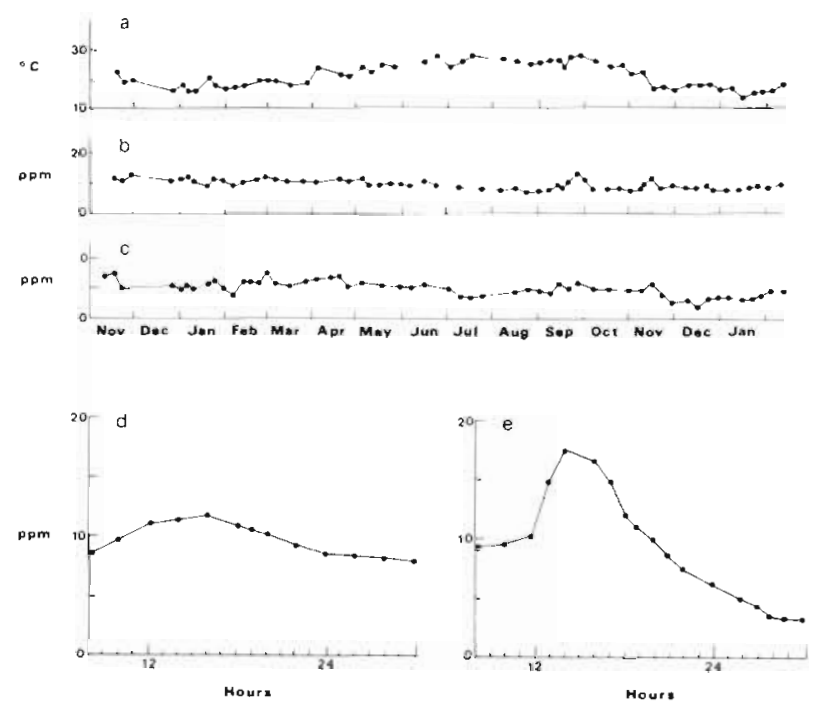

Fig. 2. (a) Annual temperature $\left({ }^{\circ} \mathrm{C}\right)$ regime in the water column. (b, c) Annual regime of dissolved oxygen (ppm) in the water column of control pond and fish pond, respectively. (d,e) Diurnal cycle of the dissolved oxygen (ppm) of control pond and fish pond, respectively, on 19 November 1978

was followed weekly and found identical (Fig. 2a). The lowest temperatures were observed during winter (November to April); they varied from $8{ }^{\circ} \mathrm{C}$ in January to $26^{\circ} \mathrm{C}$ in April. During the warm summer months (May to October), temperatures varied from $21^{\circ} \mathrm{C}$ in October to $29^{\circ} \mathrm{C}$ in July/August. The annual pH and alkalinity ranges in the ponds fluctuated only slightly, from 7.5 to 8.5 and from 2.2 to $2.6 \mathrm{mEqv}$, respectively.

The diurnal cycle of dissolved oxygen in the water column of the control pond (Fig. 2d) ranged from 7 ppm at dawn to $13 \mathrm{ppm}$ at $14.00 \mathrm{~h}$. In the fish pond the same pattern, though more pronounced, was observed ranging from 3 to $18 \mathrm{ppm}$ (Fig. 2e). The annual regime of dissolved oxygen (Fig. 2b,c), based on measurements done at $11.00 \mathrm{~h}$, exhibited the range of fluctuation observed within the diurnal cycle.

The annual mid-day ambient light regime measured at the pond site (Fig. 3a) showed exceptionally high insolation during summer, reaching $2200 \mu \mathrm{E} \mathrm{m}^{-2} \mathrm{~s}^{-1}$; it decreased to only $1300 \mu \mathrm{E} \mathrm{m}^{-2} \mathrm{~s}^{-1}$ during winter. The percentage of light reaching the bottom of the control pond varied from $17 \%$ to $78 \%$ incident illumination during the study period (Fig. 3b); it showed drastic monthly fluctuations. As expected, these variations can be correlated with phytoplankton blooms (Figs. 4a, 6a). In addition, annual variations were observed in the form of increased light penetration during the summer which corresponded to the high incident light at this period (Fig. 3a). Much less light, $2 \%$ to $4 \%$ of the incident, penetrated to the fish pond bottom (Fig 3c). This was the result of high turbidity of the water column in the fish pond, 7-14 Klett units measured at 

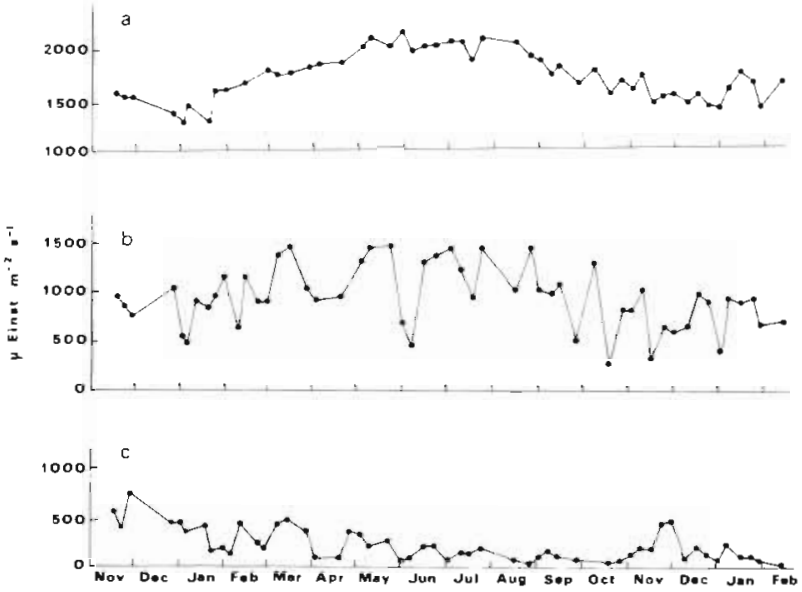

Fig. 3. Annual regime of light intensity ( $\mu$ Einsteins $\mathrm{m}^{-2} \mathrm{~s}^{-1}$ ) at (a) pond site, (b) control pond bottom, (c) fish pond bottom

$790 \mathrm{~nm}$, compared to 1 Klett unit monitored in the control pond. This turbidity was mainly caused by resuspension of silt which resulted from fish stirring up the sediment. Sedimentation trap studies showed that the resuspended particles account for $86 \%$ to $93 \%$ of the suspended material in the water column and range from 101.9 to $109.8 \mathrm{~g} \mathrm{~m}^{-2} \mathrm{~d}^{-1}$. The suspended silt dampened the monthly fluctuations as compared to the control pond, and the same low light intensity reached the bottom throughout the year (Fig. 3c).

\section{Phytoplankton and Primary Production}

The concentrations of chlorophylls $a, b$ and $c$ in control and stocked fish ponds are shown in Fig. $4 \mathrm{a}$ and $b$. In the control pond, the range of chlorophyll a concentrations was between 4 and $28 \mathrm{mg} \mathrm{Chl} \mathrm{a} \mathrm{m}{ }^{-3}$; much higher levels of 10 to $53 \mathrm{mg} \mathrm{Chl} \mathrm{am}^{-3}$ were observed in the fish pond. Strikingly, both ponds exhi-

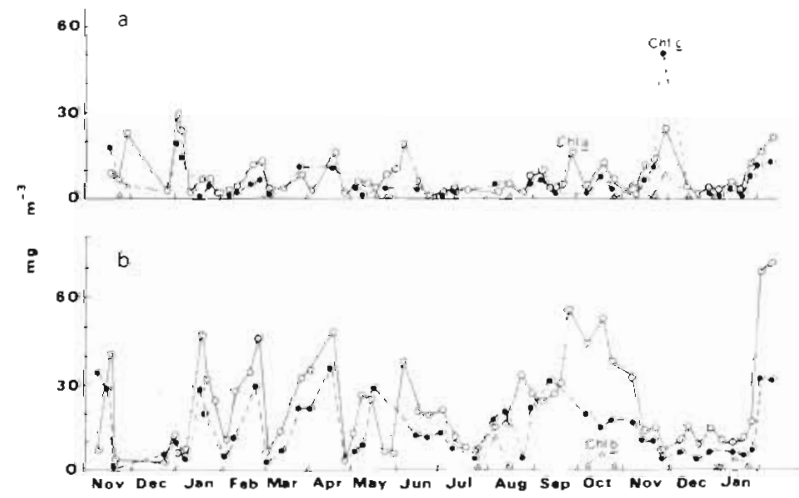

Fig. 4. Chlorophyll $a$, Chlorophyll $b$, and Chlorophyll $c$ con-

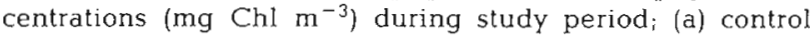
pond: (b) fish pond bited drastic monthly fluctuations but only slight seasonal effects. The standing crop of phytoplankton reached its lowest values during the summer.

Chlorophyll $c$ followed chlorophyll a ranging from

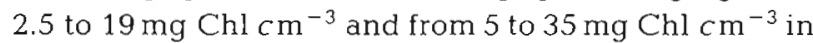
the control and fish ponds, respectively. This corresponded to the dominating centric diatomous blooms of the ponds (Fig. 6a, b). The occasional appearance of chlorophyll $b$ in both ponds correlated with sporadic Chlamydomonas sp. blooms (Fig. 6a b).

Consistent with the chlorophyll concentrations, the primary production was higher in the fish pond as compared to the control pond excluding one exceptional peak in November/December 1978. Primary production rates varied from 68 to $600 \mathrm{mg} \mathrm{C} \mathrm{m}^{-2} \mathrm{~h}^{-1}$ in the control pond and from 107 to $953 \mathrm{mg} \mathrm{C} \mathrm{m}^{-2} \mathrm{~h}^{-1}$ in the fish pond (Fig. $5 \mathrm{a}, \mathrm{b}$ ). The average daily primary production was $2 \mathrm{~g} \mathrm{C} \mathrm{m}^{-2} \mathrm{~d}^{-1}$ and $3.5 \mathrm{~g} \mathrm{C} \mathrm{m}^{-2} \mathrm{~d}^{-1}$ in the control and fish ponds, respectively. Accordingly, the annual primary production was $0.75 \mathrm{~kg} \mathrm{C} \mathrm{m}^{-2} \mathrm{yr}^{-1}$ in the control pond while in the fish pond it was $1.3 \mathrm{~kg}$ $\mathrm{C} \mathrm{m}^{-2} \mathrm{yr}^{-1}$

The primary production rates in both ponds at a depth of $50 \mathrm{~cm}$ often exceeded those measured at the surface (Fig. 5a, b). This was probably due to photoinhibition at the surface layers resulting from high insolation in this area (Fig. 3a). Below the inhibited surface layer, primary production in the control pond was constant throughout the water column suggesting equal light conditions down to the bottom throughout

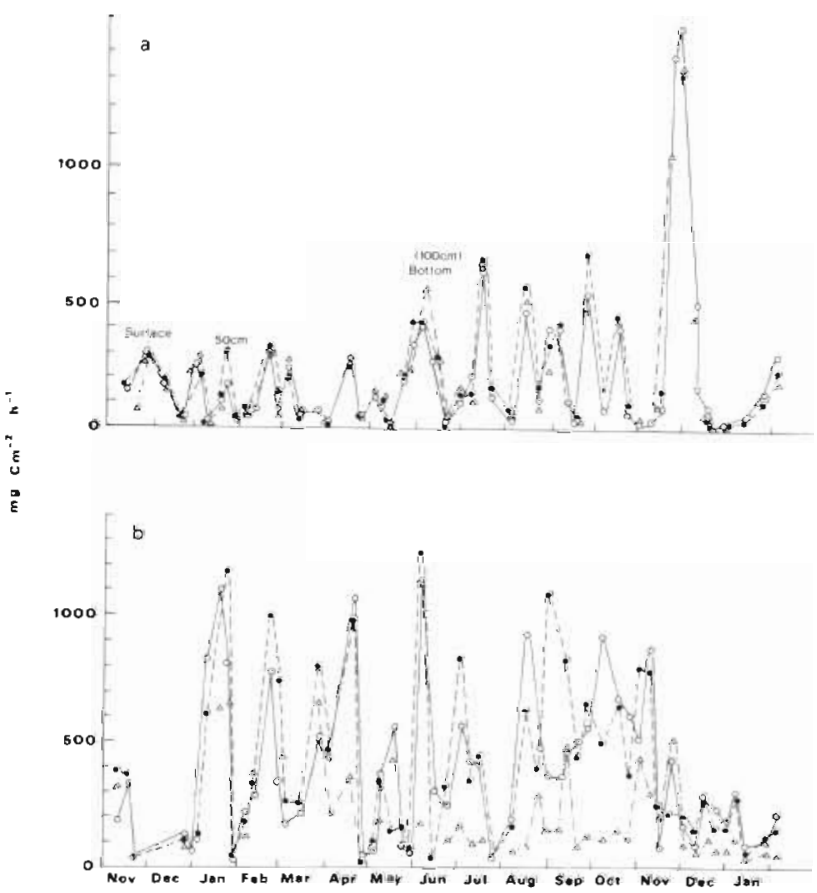

Fig. 5. Primary production ( $\mathrm{mg} \mathrm{C} \mathrm{m}^{-2} \mathrm{~h}^{-1}$ ) in (a) control pond and (b) fish pond 


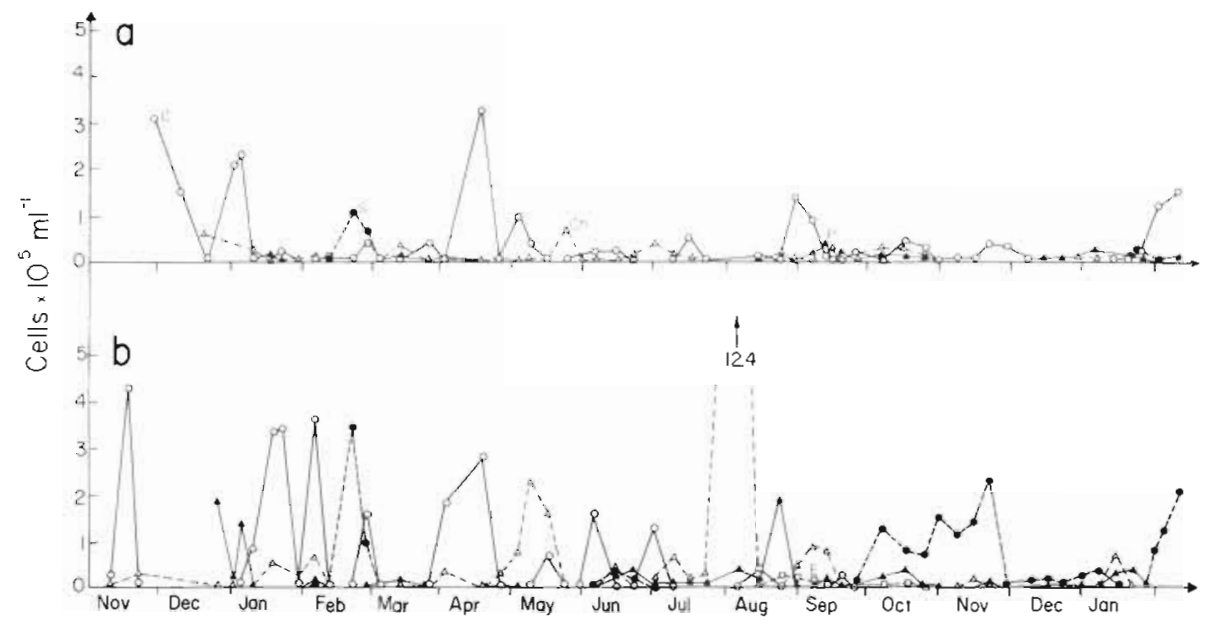

Fig. 6. Phytoplankton concentration $\left(\# \times 10^{5}\right.$ cells $\left.\mathrm{ml}^{-1}\right)$. (a) Control pond; (b) fish pond. C: Chaetoceros sp., S: Skeletonema sp., Ch: Chlamydomonas sp., P: Peridinium and Gymnodinium forms, E: Euglenoida sp

the year. The lower values observed during summer, as compared to winter measurements, implied that lightinhibiting conditions prevailed throughout the water column during this season (compare with Fig. 3b). On the other hand, primary production rate at the bottom of the fish pond was only $10 \%$ of that of the midwater value suggesting conditions of light limitation. This is probably due to the high silt suspended in the fish pond (86-93\% resuspended particles). Nevertheless, due to the very vigorous mixing allowing a particle to cross the pond in 4 min (unpubl.), each organism was exposed to a certain light condition for only a short period. Accordingly, the specific activity was virtually identical in control and fish ponds and ranged from 2-50 $\mathrm{mg} \mathrm{C} \mathrm{mg} \mathrm{Chl}^{-1} \mathrm{~h}^{-1}$, characteristic of light saturation. Furthermore, the primary production in general exhibited the same monthly periodicity as did the standing crop of chlorophyll.

The phytoplankton blooms corresponded with the monthly periodicity of the chlorophyll and primary production in both, control and fish ponds. The blooms which appeared every month lasted in general from 14 to $45 \mathrm{~d}$ in both ponds (Fig. 6a, b). The dominating phytoplankton species in the control pond was Chaetoceros $\mathrm{sp}$. which appeared in concentrations of up to $3.5 \times 10^{5}$ cells ml-1 (Fig. 6a). It appeared in the control pond throughout the year without particular seasonality. Other phytoplankton species Skeletonema sp., Chlamydomonas sp., and both Peridinium and Gymnodinium types - were usually present in small numbers and formed sporadic minor blooms. As opposed to the control pond, the phytoplankton in the fish pond exhibited seasonality.

In the fish pond, Chaetoceros sp. dominated most of the blooms from January to July in concentrations of up to $4.5 \times 10^{5}$ cells $\mathrm{ml}^{-1}$ (Fig. 6b). In the period July to September, the phytoplankton blooms consisted mainly of Chlamydomonas sp. reaching concentrations of up to $12.4 \times 10^{5}$ cells $\mathrm{ml}^{-1}$ with smaller numbers of
Peridinium and Gymnodinium types and euglenoid forms. During the transition period of September and through the winter, Skeletonema sp. was the dominant phytoplankton component appearing in concentrations of up to $3.8 \times 10^{5}$ cells $\mathrm{ml}^{-1}$ (Fig. 6b).

\section{Dissolved Inorganic Nutrients}

Dissolved inorganic nitrogen $\left(\mathrm{N}-\mathrm{NO}_{2}+\mathrm{N}-\mathrm{NO}_{3}\right)$ in inflow and pond waters is summarized in Fig. $7 \mathrm{a}, \mathrm{b}$ and

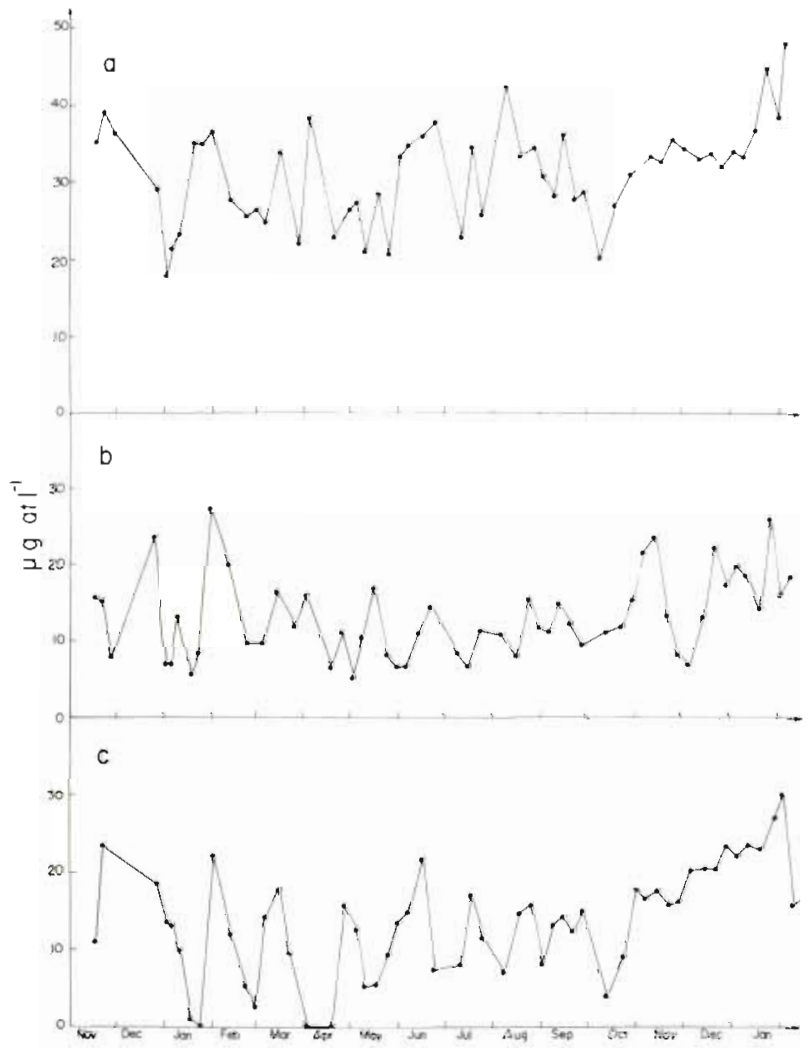

Fig. 7. Dissolved inorganic nitrogen $\left(\mu \mathrm{g}\right.$ at $\left.\mathrm{l}^{-1}\right)$. (a) Inflow water; (b) control-pond water; (c) fish-pond water 


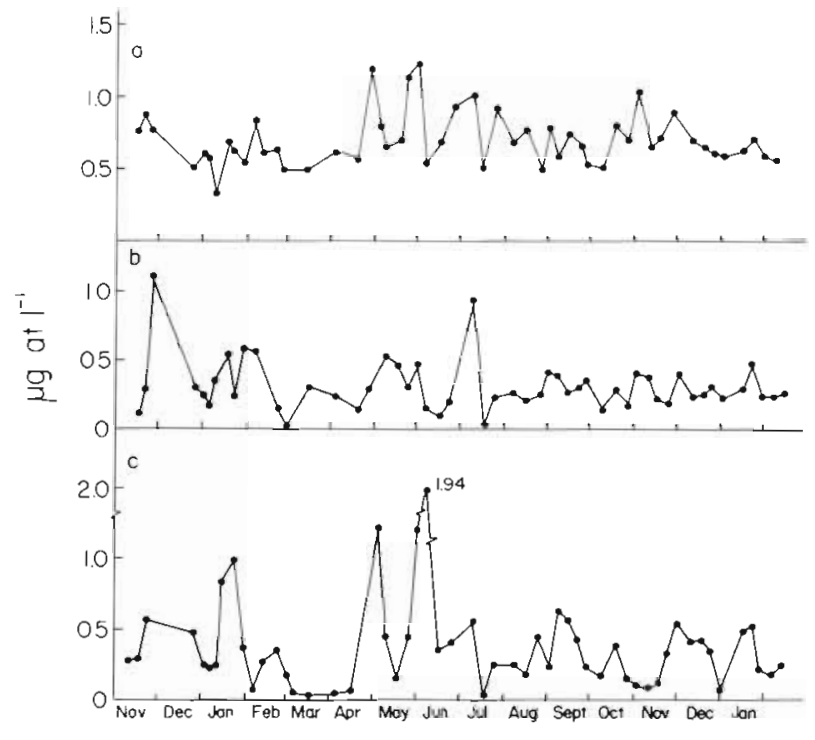

Fig. 8. Dissolved inorganic phosphorus ( $\mu$ g at $1^{-1}$ ). (a) Inflow water; (b) control-pond water; (c) fish-pond water

c. The dissolved inorganic nitrogen concentrations in the inflow showed drastic monthly fluctuations ranging from 18 to $44 \mathrm{~g}$ at $\mathrm{Nl}^{-1}$. The dissolved inorganic nitrogen in the water column of the ponds fluctuated monthly according to the periodicity of the phytoplankton blooms, the peaks of the blooms coinciding with the dissolved nitrogen troughts (Figs. $4 a, b ; 5 a, b$ ). The range of dissolved inorganic nitrate concentration in the control pond varied from 5 to $28 \mu \mathrm{g}$ at $\mathrm{Nl}^{-1}$, while in the fish pond the range was from 0 to $32 \mu \mathrm{g}$ at $\mathrm{Nl}^{-1}$. Concentrations of ammonia were found to be below detection levels - less than $1 \mu \mathrm{g}$ at $l^{-1}$.

The concentrations of dissolved inorganic orthophosphate $\left(\mathrm{P}-\mathrm{PO}_{4}\right)$ in inflow and pond water of control and fish ponds are summarized in Fig. 8a, b and c. Like the dissolved nitrogen, the dissolved inorganic orthophosphate concentrations in the inflow water fluctuated monthly with concentrations ranging from 0.3 to $1.25 \mu \mathrm{g}$ at $\mathrm{Pl}^{-1}$.

In the water column, the dissolved inorganic orthophosphate followed the monthly phytoplankton bloom fluctuations with a range of 0 to $1.2 \mu \mathrm{g}$ at $\mathrm{Pl}^{-1}$ in the control pond, and 0.02 to $1.94 \mu \mathrm{g}$ at $\mathrm{Pl}^{-1}$ in the fish pond.

Dissolved silica was very high in the inflow and fluctuated between 40 and $140 \mu \mathrm{g}$ at $\mathrm{Si} \mathrm{l}^{-1}$. In the water column of the control pond, the dissolved silica ranged from 12 to $141 \mu \mathrm{g}$ at Si $1^{-1}$, while in the fish pond it was 23 to $120 \mu \mathrm{g}$ at $\mathrm{Si} \mathrm{l}^{-1}$.

\section{DISCUSSION}

Clearly, the phytoplankton biomass of the fish pond was much higher than that of the control pond.
Whereas in the former, the average chlorophyll a con-

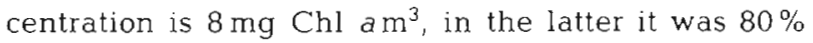
higher. Both ponds were supplied from a single well. Hence, both ponds received the same nutrient load in the inflow which amounted to an average of $2.7 \mathrm{~g}$ at nitrogen $\mathrm{d}^{-1}$ and $0.065 \mathrm{~g}$ at phosphorus $\mathrm{d}^{-1}$. The fish pond, however, received an extra nutrient load from fish food which amounted to $1.9 \mathrm{~g}$ at nitrogen and $0.14 \mathrm{~g}$ at phosphorus $\mathrm{d}^{-1}$. This extra load was probably responsible for the higher standing crop observed in the fish pond. Furthermore, this response of the phytoplankton to the addition of nutrients may indicate that a nutrient limitation existed in these ponds. Strikingly, indeed, both ponds showed the same pattern of monthly periodicity. Phytoplankton blooms synchronously appeared in both ponds and developed within 7 to $22 \mathrm{~d}$. Thereafter, a rapid collapse of the biomass

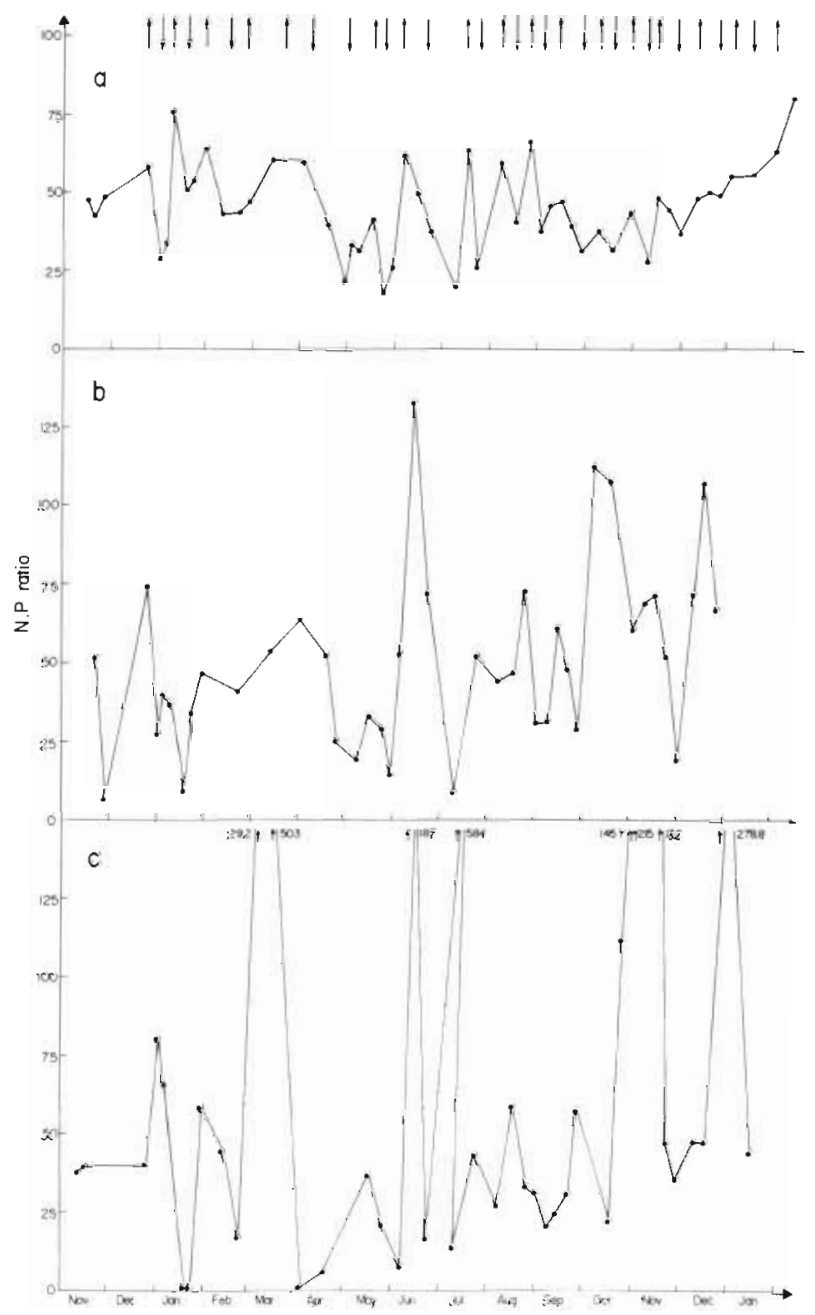

Fig. 9. N:P ratio in inflow water (a), control-pond water (b), and fish-pond water (c). Average daily tide in Gulf of Elat in 1977-1979 varied from $+40 \mathrm{~mm}$ to $-45 \mathrm{~mm}$ (Israel Meteorological Service). Occurrence of monthly high tide ( $\uparrow$ ) and low tide $(\downarrow)$ is indicated 
ensued within 7 to $22 \mathrm{~d}$. It must be concluded that a common nutrient in both ponds became limited every month; it was most likely related to the common water source.

It was observed that the $\mathrm{N}$ : $\mathrm{P}$ ratio in the inflow water was high, ranging from 18 to 80 (Fig. 9a). Furthermore, drastic monthly fluctuations were observed which clearly correlated with the blooms, suggesting that the system was generally phosphorus limited. Thus, the monthly decrease in the N:P ratios in the inflow correlated to the rise of the phytoplankton bloom, while the $\mathrm{N}$ : $\mathrm{P}$ ratio increase corresponded to the phytoplankton collapse. The N:P ratio fluctuations in the pond were a function of both the N:P ratio of the inflow water and the activity of the phytoplankton blooms. Hence, the fluctuations in the pond N:P ratios were more drastic and rapid, ranging from 8 to 140 and from 2 to 584 in the control and fish ponds, respectively (Fig. 9b, c). Toward the peak of the bloom, the N:P ratios decreased rapidly due to active uptake of nutrients by the phytoplankton. After the collapse of the bloom, the $\mathrm{N}$ :P ratios increased temporarily and the mineralized nutrients were washed out of the pond. It should be noted that nitrogen limitation may develop very rarely as seen in low N:P ratios of 2 to 8 (Fig. 9b, c). The dissolved silica was found to be abundant in the inflow and in the ponds throughout the study period and can thus be ruled out as a possible limiting factor.

The seawater well supplying the waters of the ponds is hydrologically connected to the littoral of the Gulf and groundwater. The dissolved primary nutrient concentrations in the littoral were measured to be only 0.15 to $0.36 \mu \mathrm{g}$ at $\mathrm{Nl}^{-1}$ nitrate and 0.03 to $0.08 \mu \mathrm{g}$ at $\mathrm{Pl}^{-1}$ phosphate (Sournia, 1977). These concentrations were much lower than those in the well, strongly indicating that the groundwater was the major nutrient contributor to the well. The salinity of the well was slightly lower $(10 \%)$ than that of the open Gulf (Krant et al, in press).

Yet the fluctuations in the N:P ratios in the well waters, as measured in the ponds' inflow waters, correlated with the tidal pattern measured in the Gulf. Inflow N:P ratios were lowest at monthly low tide and highest at monthly high tide (Fig. 9a). It is suggested that the tide differentially changed the contribution of nutrients from the groundwater and seawater and thus affected the N:P ratio. The mechanism of this influence, however, is not yet clear. The tide-controlled fluctuations in the N:P ratio of the inflow water were correlated with the phytoplankton blooms in the ponds. At low tide, when the N:P ratio in the inflow water was low, the phytoplankton bloom developed; and during the high tide, when the N:P ratio was increased in the inflow water, the blooms collapsed.

Regardless of the drastic fluctuations, the overall primary production level in the fish pond amounted to $1.3 \mathrm{~kg} \mathrm{C} \mathrm{m}{ }^{-2} \mathrm{yr}^{-1}$ which is similar to that observed in freshwater fish ponds (Hepher, 1962; Norriega-Curtis, 1979). An increased phytoplankton production could probably be obtained by additional phosphate input during high tide periods when phosphorus limitation was observed. Preliminary results confirm this prediction. After the elimination of nutrient limitation, the system would ultimately be light limited, due to the high silt density in the fish ponds. The removal of the silt would therefore lead to higher productivity until the system would again reach light limitation due to self shading. As calculated from the cell concentrations and the dilution rates, the apparent growth rates of the phytoplankton during the blooms varied in the control pond from 0.62 to $1.60 \mathrm{~d}^{-1}$ and in the fish pond from 0.64 to $1.70 \mathrm{~d}^{-1}$. The apparent growth rates of the phytoplankton corresponded with the highest values observed in other nutrient-rich marine waters (Thomas, 1977). Hence, it is unlikely that the phytoplankton production could be enhanced by an increased dilution rate.

It is apparent that the addition of fish food, and the presence of fish, resulted in a faster eutrophication rate in the fish pond as compared to the control pond. Linear regression of the annual fluctuations in chlorophyll a have shown that the slope of the regression line corresponds to a daily increase of $0.032 \mathrm{mg}$ Chl a $\mathrm{m}^{-3} \mathrm{~d}^{-1}$, compared to a negligible increase of merely $0.00057 \mathrm{mg} \mathrm{Chl} \mathrm{a} \mathrm{m}^{-3} \mathrm{~d}^{-1}$ in the control pond. The very slow rate suggests that the fish pond had reached the steady state.

Although the overall production in the seawater fish ponds was similar to that of freshwater fish ponds, the former did not reach conditions as stagnant as those observed in the latter ponds. The seawater fish ponds were continuously flushed at a dilution rate of $0.6 \mathrm{~d}^{-1}$ and the wind vigorously mixes the water. Hence, only very rarely, when there was no wind and when the mixing stopped for a long time during a dense bloom, did occasional fish mortalities occur due to high oxygen. The very short retention time of the water prevented a buildup of fish growth-inhibiting factors in the water column. Nevertheless, a decrease of the fish growth rate was observed in the marine fish ponds (Gordin et al., 1980). Temporal but frequent increase in harmful substances during the dramatic monthly collapse of the bloom must be considered as a factor inhibiting the fish growth. Preliminary daily measurements showed that even during bloom collapse, the concentrations of ammonia did not exceed 1-2 $\mu \mathrm{g}$ at $\mathrm{l}^{-1}$. Another possibility is the accumulation of fishgrowth inhibiting substances in the sediment. Preliminary observations have shown up to $12 \%$ dry organic matter in the sediment. The interstitial water in the 
organic sediment contained up to $200 \mu \mathrm{g}$ at $\mathrm{N}-\mathrm{NH}_{4} \mathrm{l}^{-1}$ and up to $300 \mu \mathrm{g}$ at sulfide. Both compounds have been shown to be harmful to fish (Reichenbach-Klinke, 1967; Amlacher, 1970; Kinne, 1976). It was observed that the fish in the ponds frequently dug into the sediments and thus were exposed to the very high concentrations of ammonia and sulfides. These exposures may have had a cumulative effect which may have resulted in growth retardation. The possible role of the sediments in the biology of the fish ponds is currently being studied in Israel and elsewhere.

Acknowledgements. The authors would like to express thanks to Dr B. Scharfstein for his helpful suggestions concerning the manuscript. This study was supported jointly by the GKSS Forschungszentrum Geesthacht $\mathrm{GmbH}$, Federal Republic of Germany, and the Israel National Council for Research and Development.

\section{LITERATURE CITED}

Abeliovich, A. (1969). Water bloom of blue green algae. Proc. Sci. 17: 594-601

Abeliovich, A., Shilo, M. (1972). Photooxidative death in blue green algae. J. Bacteriol. 111: 682-689

Abram, J. W., Nedwell, D. B. (1978). Inhibition of methanogenesis by sulphate reducing bacteria competing for transferred hydrogen. Arch. Microbiol. 117: 89-92

Amlacher, E. (1970). Textbook of fish diseases, T. F. H. Publ. Inc., Jersey City, N.J.

Assaf, G., Kessler, J. (1976). Climatic and energy exchange in the Gulf of Aqaba (Elat). Mon. Weather Rev, 104: 381-385

Avnimelech, $Y_{.}$, Lacher, M. (1979). A tentative nutrient balance for intensive fish ponds. Bamidgeh 31:3-8

Bardach, J. E., Ryther, J. H., McLarney, W. D. (1972). Aquaculture: the farming and husbandry of freshwater and marine organisms, Wiley-Interscience, New York

Brezonik, P. L. (1972). Nitrogen: sources and transformation in natural waters. In: Allen, H. E., Kramer, J. R. (eds.) Nutrients in natural waters. Wiley, New York, pp. 1-50

Cappenberg. T. E. (1974). Interrelations between sulphatereducing and methane producing bacteria in the bottom deposits of a freshwater lake. II. Inhibition experiments. Antonie van Leeuwenhoek 40: 297-306

Colt, J., Tchobanoglous, G. (1978). Chronic exposure of channel catfish Ichthalurus punctarus to ammonia: effects on growth and survival. Aquaculture 15: 353-372

Dimitrov, M. (1974). Mineral fertilization of carp ponds in polycultural rearing. Aquaculture 3: 273-285

Ellof, J. N., Steinitz, Y., Shilo, M. (1976). Partial photooxidation of cyanobacteria in natural conditions. Appl. environ. Microbiol. 31: 119-126

Goldman, J. C., Ryther, J. H. (1975). Nutrient transformations in mass cultures of marine algae. J. environ. Engng Div. 101: 351-364

Goldman, J. C., Tenore, K. R., Stanley, H. I. (1973). Inorganic nitrogen removal from wastewater: effect on phytoplankton growth in coastal marine waters. Science, N.Y. 180 955-956

Gordin, H., Motzkin, F., Hughes-Games, W. L., Porter, C. (1981). Seawater mariculture pond - an integrated system. In: Rosenthal, H., Oren, O. H. (eds.) European Mariculture Society Spec. Publ. 6: 1-14

Grasshoff, K. (1976). Methods of seawater analysis, Verlag Chemie, Weinheim, New York
Halevi, A. (1979). Observations on polyculture of fish under standard farm pond conditions at the fish and aquaculture research station, Dor, during the years 1972-1977. Bamidgeh 31: 96-104

Harvey, H. H., Smith, S. B. (1961). Supersaturation of the water supply and occurrence of gas bubble disease at Cultus Lake trout hatcheries. Can. Fish. Cult. 30: 39-47

Hepher, B. (1962). Primary production of fish ponds and its application to fertilization experiments. Limnol. Oceanogr. 7: 131-136

Hepher, B. (1975). Supplementary feeding in fish culture. In: Proceedings 9th International Congress Nutrition, Mexico, 1972, Vol. 3. Karger, Basel, pp. 183-198

Huguenin, J. E. (1975). Development of marine aquaculture research complex. Aquaculture 5: 135-150

Jørgensen, B. B., Fenchel, T. (1974). The sulphur cycle of a marine sediment model system. Mar. Biol. 24: 189-201

Kinne, O. (1976). Cultivation of marine organisms: waterquality management and technology. In: Kinne, O. (ed.) Marine ecology, Vol. III, Cultivation, Part I. Wiley, New York, pp. 19-300

Krant, J. (1979). Estimating fish pond temperatures from simple weather data. M. Sc. thesis, The Weizmann Institute of Science, Rehovot

Krant, J., Motzkin, F., Gordin, H. (1982). Modeling temperatures and salinities of mixed fish ponds. Aquaculture 27 in press

Marais, J. F. K., Kissil, G. Wm. (1979). The influence of energy level on the feed intake, growth, food conversion and body composition of Sparus aurata. Aquaculture 17: 203-219

Moav, R., Wohlfarth, G., Schroeder, G. L., Hulata, G., Barash, H. (1977). Intensive polyculture of fish in freshwater ponds. I. Substitution of expensive feeds by liquid cow manure. Aquaculture 10: 25-43

Norriega-Curtis, P. (1979). Primary productivity and related fish yields in intensely manured fish ponds. Aquaculture 17: 335-344

Pauley, G. B., Nakatani, R. E. (1967). Histopathology of gas bubble disease in salmon fingerlings. J. Fish. Res. Bd Can. $24: 867-871$

Rappaport, V., Sarig, S. (1979). The effect of population density of carp in monoculture under conditions of intensive growth. Bamidgeh 31: 26-34

Reichenbach-Klinke, H. H. (1967). Untersuchungen über die Einwirkung des Ammoniakgehaltes des Fischorganismus. Arch. Fisch. Wiss. 17: 122-132

Ryther, J. A., Goldman, J. C., Gifford, C. E., Huguenin, J. E., Wing, A. S., Clarner, J. P., Lavergne, D., Lapointe, W., Brian, E. (1975). Physical models of integrated waste recycling - marine polyculture systems. Aquaculture 5: 163-177

Schroeder, G. L. (1978). Autotrophic and heterotrophic production of micro-organisms in intensely manured fish ponds, and related fish yields. Aquaculture 14: 303-325

Seymour, E. A. (1980). The effects and control of algal blooms in fish ponds. Aquaculture 19: 55-74

Sournia, A. (1977). Notes on primary productivity on coastal waters in the Gulf of Elat (Red Sea). Int. Revue ges. Hydrobiol. 62: 813-819

Strickland, J. D. H., Parsons, T. R. (1968). A practical handbook of seawater analysis. Fish. Res. Bd Can., Bull. 167: $1-311$

Thomas, W. H. (1977). Nutrient-phytoplankton interrelationships in the eastern tropical Pacific Ocean. Inter-American Tropical Tuna Commission, La Jolla, California, Bull. 17: $173-212$

Wolfe, R. S. (1971). Microbial formation of methane. Adv. Microbial Physiol. 6: 107-147 